\title{
SEASONAL RESOURCE SELECTION, RECRUITMENT, DIET SELECTION AND TIME BUDGETS OF BIGHORN SHEEP (OVIS CANADENSIS) IN THE TETON RANGE, NORTHWEST WYOMING
}

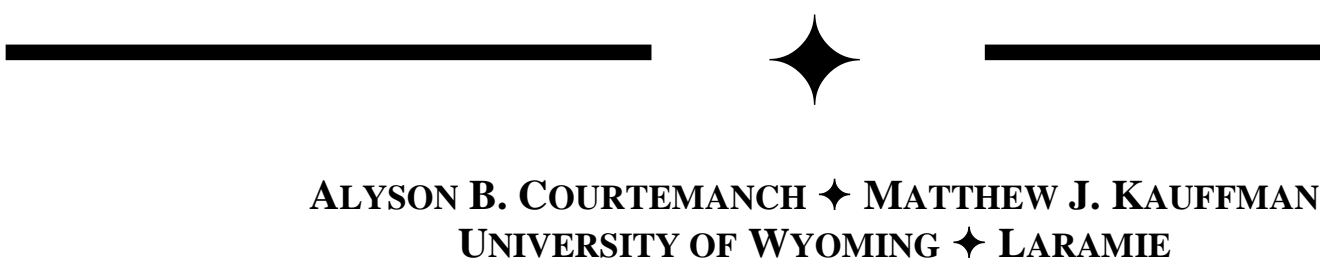

\section{$\uparrow \quad$ ABSTRACT}

Many ungulate populations have lost access to their traditional migration routes and seasonal ranges, resulting in rapid and severe population declines. Some ungulate populations have been able to adapt to living year-round on one seasonal range and persist despite loss of migration. However, our understanding of how ungulates adapt their habitat selection and foraging strategies in order to compensate for migration loss is poor. This study investigates how a formerly migratory, now sedentary and isolated, bighorn sheep (Ovis canadensis) population persists year-round on highelevation summer range in the Teton Range in northwest Wyoming. We captured and GPS-collared 20 bighorn ewes throughout the Teton Range in February 2008 and an additional 8 ewes in March 2009. In 2008, ninety percent of captured ewes were pregnant, and $100 \%$ were pregnant in 2009 . During summers 2008 and 2009, we located and observed GPS-collared ewes, determined lamb survival, collected fecal samples for diet composition analysis, conducted vegetation surveys, and observed timebudgets. We found that $50 \%$ of lambs survived until at least mid-summer in 2008 and $60 \%$ survived in 2009. We observed differences in movement patterns between GPS-collared ewes during the summer seasons, ranging from $5 \mathrm{~km}$ to a maximum of $15 \mathrm{~km}$. At this time, eight GPS-collared ewes have died (4 in avalanches, 1 from predation, and 3 unknown). This study is ongoing and will be completed in 2011. Results will directly contribute to management of this non-migratory and isolated bighorn sheep population, and will shed light on how a formerly migratory ungulate population has been able to persist on high-elevation range year-round.

\section{$\uparrow \quad$ INTRODUCTION}

Animal migration is one of the most spectacular natural phenomena on the planet. Despite its inherent appeal to the human imagination, we are only beginning to understand the connections between migration, ungulate population limitation, and the ecological consequences of migration disruption and loss (Bolger, Newmark et al. 2008). Over the past two centuries, ungulate migrations around the world have been threatened due to human activities, commonly in the form of anthropogenic barriers or land conversion coupled with habitat loss (Bolger et al. 2008). Where migration routes have been disrupted or lost, the result is often rapid population decline and at the extreme, local extinction (Newmark 1996; Mwangi 1998; Bolger et al. 2008). For example, between the late 1970s and 1990s, there was an $81 \%$ decline in the wildebeest (Connochaetes taurinus) population in the Masai Mara ecosystem in southern Kenya attributed to conversion of wet season calving and breeding range to agricultural uses (Ottichilo et al. 2001, Serneels and Lambin 2001).

Loss of access to winter, dry season, or breeding ranges appears to reduce carrying capacity, 
although the exact nature of the mechanisms and effect on ungulate populations is unclear (Bolger et al. 2008). While some ungulate populations experience severe declines and local extinctions after the loss of traditional migration routes, some populations continue to persist, although with lower numbers (Whitfield 1983). In such cases, it is unknown how ungulate populations behaviorally adapt to living year-round on one seasonal range. Our current understanding of ungulate migration losses begs the following questions: How do ungulates alter their habitat selection strategies in order to survive in a sub-optimal habitat for at least part of the year? What novel pressures do sedentary, non-migratory ungulates face and how do they cope with them? Which species and ecosystems are best able to persist after migration routes have been lost?

Due to their specialized habitat requirements (i.e., proximity to escape terrain, good horizontal visibility) bighorn sheep (Ovis canadensis) have a naturally fragmented distribution, with habitat patches connected by traditional non-habitat movement corridors (Risenhoover et al. 1988; Bleich et al. 1990, Valdez and Krausman 1999). This naturally fragmented distribution was exacerbated by the arrival of Euro-Americans to the West in the late 1800 s, which caused a catastrophic decline of bighorn sheep numbers due to the combined effects of disease (primarily scabies caused by the Psoroptes mite), overhunting, competition for forage with domestic livestock, and displacement from winter range (Buechner, 1960). This decline resulted in many small, isolated populations and loss of traditional migration corridors (Risenhoover et al., 1988). More recent habitat losses from agricultural, industrial, and recreational developments, fire suppression, and anthropogenic barriers to movement such as roads and fences have led to further disruptions of historic bighorn sheep migrations and inter-population connectivity. Since bighorn sheep are poor colonizers of new habitats (Risenhoover et al., 1988), they are particularly vulnerable to population decline and local extirpation from loss of traditional migration routes and seasonal range reduction.

Like many ungulates, most bighorn sheep populations undertake seasonal altitudinal migrations (Shackleton et al. 1999). Seasonal altitudinal movements allow bighorn sheep to access the highest quality and most digestible forage available within their home range. Bighorn sheep are able to take advantage of low elevation vegetation growth in spring and follow new growth to higher elevations, accessing nutritious forage into mid and late summer
(Klein 1965). Hebert (1973) concluded that altitudinal migration was essential to maintaining seasonal bighorn sheep nutrition.

The Teton Range bighorn sheep herd in northwest Wyoming is an example of a sheep population that has abandoned its historic migration to low-elevation winter range. Prior to the arrival of Euro-American settlers to Jackson Hole and Teton Valley in the late 1800 s, bighorn sheep wintered in the foothills and valleys surrounding the Teton Range. However, due to a number of factors including human development, widespread domestic sheep grazing, fire suppression, and construction of roads and fences, bighorn sheep abandoned their historic migration routes and by the mid-1900s became a non-migratory, isolated population summering and wintering at high elevations in the Teton Range (Whitfield 1983, Reid and Cain 1996). Nevertheless, the herd continues to persist and provides us an opportunity to investigate how an ungulate population responds to migration loss.

The main objectives of this study are to: 1) compare bighorn sheep habitat selection during summer and winter, and 2) evaluate bighorn sheep avoidance of suitable winter habitats where human recreation occurs. These objectives will be addressed mainly with data from GPS-collars and winter field work. However, we are also gathering supplemental information during summer seasons about relatively unknown vital rates for this population (i.e., adult mortality and lamb survival), forage selection, and time-budgets (time spent foraging vs. time spent vigilant) to compare with data from migratory sheep populations. We hypothesize that in order for this non-migratory population to persist year-round on high elevation summer range, they may exhibit different foraging strategies and anti-predator behaviors than migratory sheep populations in similar habitats.

\section{STUDY AREA}

The Teton Range bighorn sheep herd resides year-round at high elevations in Grand Teton National Park (GTNP), Bridger-Teton National Forest (BTNF), and Caribou-Targhee National Forest (CTNF) (Figure 1). The Teton herd is Wyoming's smallest and most isolated native herd - a remnant population of perhaps 100-150 sheep derived from a much larger bighorn sheep complex that historically occupied northwest Wyoming. Unlike many other bighorn sheep herds in the Rocky Mountain West, the Teton herd has yet to experience a transplant to augment population size (Hurley, 1996). 


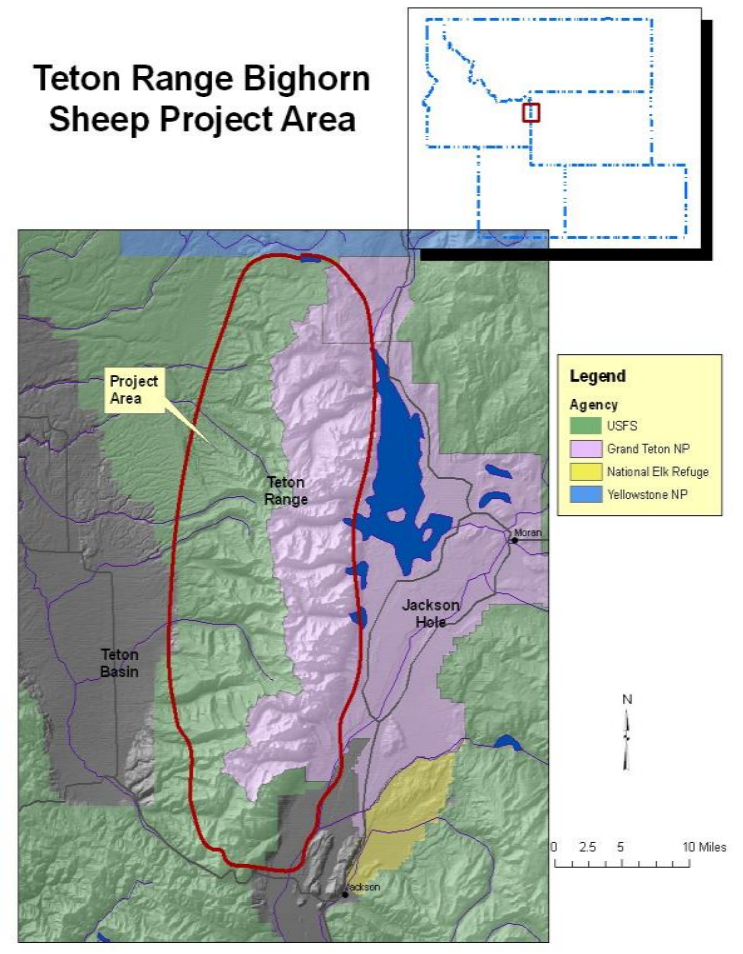

Figure 1. Project study area.

Growing recognition of the tenuous status of the Teton bighorn sheep population and the need for interagency cooperation in managing the herd led to the formation of the Teton Range Bighorn Sheep Working Group (TRBSWG) in 1990. This group identified a number of threats to the herd's future persistence including small population size, genetic isolation from surrounding herds, limited and poor quality winter range, and disturbance from increasing winter backcountry recreation (Teton Range Bighorn Sheep Working Group 1996). Wildlife biologists and managers in the area are striving to develop effective strategies to manage this herd without having to augment numbers with a transplant.

\section{$\uparrow \quad$ METHODS}

\section{Capture and GPS-collaring}

To evaluate bighorn sheep seasonal habitat selection, Telonics GPS store-on-board collars (Telonics, Inc., Mesa, Arizona, U.S.A.) were deployed on 20 ewes in February 2008. Ewes were captured by net-gunning from a helicopter (Leading Edge Aviation, Lewiston, Idaho) throughout the Teton Range (Figure 2). The GPS collars are programmed to collect a GPS fix every five hours during the winter (15 November - 15 April) and summer (15 June - 15 September) and every 25 hours during the fall (16 September - 14 November) and spring (16 April- 14 June). The collars are programmed to drop off on 15 July 2010, yielding about $2 \frac{1}{2} 2$ years of data. During captures, blood (20 cc) was collected from all ewes for pregnancy and disease analysis, and ear swabs for mite testing. Fecal, tissue, and an additional blood sample were collected from all ewes for contribution to a genetic study being implemented by Grand Teton National Park. In addition, we estimated age with horn ring counts, and we recorded capture and release times.

In March 2009, we captured and GPScollared an additional 8 bighorn ewes, implementing the same capture techniques as in the previous year (Figure 2). We collected the same biological samples for pregnancy, disease, and genetic testing, recorded horn rings, capture and release times, and weighed individuals.

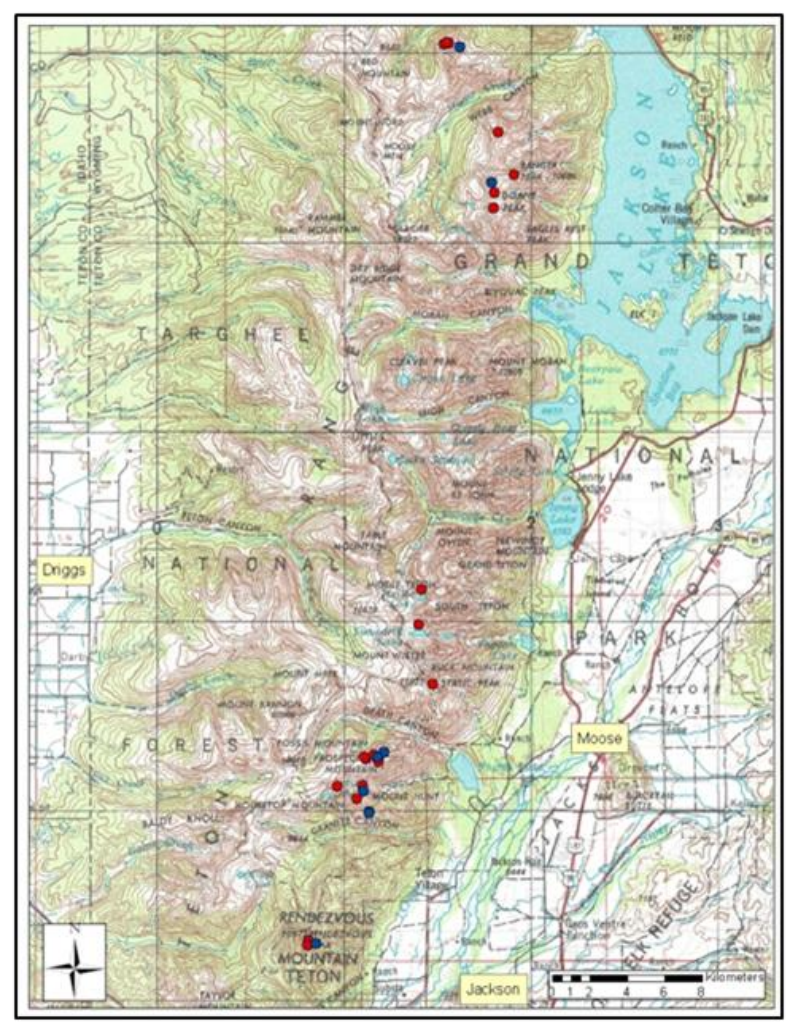

Figure 2. Bighorn sheep capture locations in the Teton Range, February 2008 (red) and March 2009 (blue).

\section{Monitoring adult mortality}

In order to monitor for GPS-collared sheep mortalities and obtain general locations of sheep throughout the study period, monthly telemetry flights were conducted with a fixed-wing aircraft (Sky Aviation, Driggs, Idaho). These flights were 
increased to two times per month during the summer season (June - August) to assist field crews in locating GPS-collared sheep from the ground. All of the GPS collars contain an activity sensor, which is programmed to switch the collar to mortality mode after 6 hours of inactivity (VHF pulse rate switches to 100 beats per minute instead of 45 BPM for an active animal). Mortalities were investigated as soon as possible on the ground with standard necropsy procedures.

\section{Summer field data collection}

During summers 2008 and 2009, we collected data in the field to enhance our understanding of bighorn sheep demography, diet, and time-budgets in the Teton Range. After the completion of data collection in summer 2010, we will compare the forage selection, time-budgets, and lamb survival of the non-migratory Teton bighorn sheep population with findings from studies of migratory sheep populations in similar habitats.

\section{Lamb survival}

During summers 2008 and 2009, field crews monitored lamb survival for GPS-collared ewes from June to August. Field crews spent 4-5 days in the backcountry at a time, and located and observed each GPS-collared ewe at least four times to determine the presence or absence of a lamb. We identified lamb/ewe pairs by observing suckling behavior. In bighorn sheep, it is rare for a ewe to allow a lamb other than her own to suckle (Valdez and Krausman 1999). In addition to lamb survival, we also recorded bighorn sheep group sizes and composition.

\section{Diet composition}

We collected bighorn sheep fecal samples from June to August 2008 and 2009 for diet composition analysis at the Washington State University Wildlife Habitat and Nutrition Laboratory in Pullman, Washington. Fresh samples from 2008 were combined into three composite samples to represent bighorn sheep diets in June, July, and August. Fecal samples from 2009 were combined into three composite samples to represent diets in July for the southern group, July for the northern group, and August for the southern group. Our aim was to compare diet composition between months and between the northern and southern groups. Major forage plants ( $>5 \%$ of diet) and the percent content of forage classes (grass, shrub, forbs, etc.) were identified. These data will be compared to other bighorn sheep foraging studies to determine whether this herd selects summer forage differently than migratory sheep herds.

\section{Time-budgets}

Non-migratory and migratory ungulates may exhibit different seasonal patterns of foraging and vigilance behaviors. Non-migratory bighorn sheep that winter at high elevations may have to spend more time foraging and less time being vigilant during the summer in order to consume enough calories to survive on relatively marginal forage during the winter. Bighorn sheep in the Teton Range may be forced to rely on their fat reserves during winter to a larger extent than migratory populations. During summer 2008 and 2009, field crews located groups of bighorn sheep and conducted time-budget observations to determine percent of time spent foraging vs. percent of time spent vigilant for predators. After locating a group, we observed each individual in the group for 15 minutes, and calculated the proportion of time spent foraging, vigilant, moving, standing, and bedded. We began individual observations only when an animal was actively feeding or searching for food (Frid 1997). In addition, a group scan was conducted every 5 minutes during each 15-minute observation period and behaviors were recorded for all individuals in the group. For each focal individual, we recorded sex, approximate age, and presence of lamb, as well as group size, composition, and estimated distance from escape terrain, all of which have been found to influence anti-predator behavior in ungulates (Berger 1978, Frid 1997, Lung and Childress 2006).

\section{RESULTS \& DISCUSSION}

\section{Captures}

The average estimated age of captured ewes was 4.35 years $(\min =1$ year, $\max =8$ years $)$ in 2008 and 3.25 years $(\min =2$ years, $\max =4$ years $)$ in 2009. The average weight of ewes in 2009 was $59 \mathrm{~kg}$ $(\min =50 \mathrm{~kg}, \max =66 \mathrm{~kg})$. Average processing time for captured ewes in 2008 was 10 minutes (min $=5$ minutes, $\max =13$ minutes ), and 16.5 minutes ( $\min =9$ minutes, $\max =28$ minutes $)$ in 2009 . The increase in 2009 was due to extra time needed for weighing individuals.

\section{Pregnancy and disease testing}

Pregnancy testing revealed that 17 of 19 ewes of reproductive age $(90 \%)$ were pregnant in 
2008. In 2009, $100 \%$ of ewes were pregnant. These percentages suggest sheep are gaining sufficient fat during summer on high-elevation range to become pregnant and maintain reproductive status through late-winter.

In 2008 and 2009, captured ewes tested negative or had extremely low titers for 12 common bighorn sheep diseases: caprine arthritis encephalitis, ovine progressive pleuropneumonia, infectious bovine rhinotracheitis, bovine viral diarrhea, parainfluenza virus, respiratory synctial virus, bluetongue, Johne's disease, Brucella ovis, wildlife brucellosis serology, epizootic hemorrhagic disease virus, and Psoroptes mites. These results indicate very low previous disease exposure for this isolated population. Mannheimia haemolytica was isolated from tonsil and nasal swabs from one captured ewe, although she remains alive and show no visual signs of being affected by the bacteria. Of special note are the low titers results for parainfluenza virus, to which nearly $100 \%$ of Wyoming ungulates have been exposed (H. Edwards, pers. comm.).

For the time being, these results are reassuring because they do not indicate any immediate disease threat to the Teton herd. However, the low titers suggest that this population is naïve to many diseases, which puts it at risk of a severe population decline if a disease does turn up in the future. Also, the tradeoff of benefits and risks of a potential transplant will have to be seriously considered by wildlife biologist and managers. The risk of introduction of disease into the Teton herd through a transplant may outweigh the benefit of increasing population numbers and genetic diversity.

\section{Adult mortality and lamb survival}

Thus far, 8 GPS-collared bighorn ewes have died during the study period. Three were killed in spring avalanches, 1 died in a winter avalanche, 1 was predated by a mountain lion, and 3 died of unknown causes (Figure 3). This mortality rate for adult females appears high especially for a relatively small population, however, our sample at this time remains low.

We observed each GPS-collared ewe at least 4 times throughout the summer field seasons and determined that $50 \%$ of lambs from GPS-collared ewes survived until at least mid-summer in 2008 and $60 \%$ in 2009 , which is a typical summer survival rate (Geist 1971, Valdez and Krausman 1999). Very little is known about the demography of this isolated, nonmigratory herd, so even though our sample size is small, gathering information on lamb survival and adult mortality is informative to managers in determining the need for a future demographic study or monitoring efforts. We will continue to collect lamb survival data during summer 2010.

\section{Summer observations and movement}

In summer 2008, we observed 229 bighorn sheep (many are repeat observations) on 42 different occasions. In summer 2009, we observed 356 sheep on 81 different occasions. The increase in summer 2009 in observations likely is a reflection of increased knowledge of the study area and efficiency in finding and observing sheep groups. The average group size observed in 2008 was 5.5 individuals (min $=1, \max =16)$ and in 2009 it was 4.4 individuals $(\min =1, \max =20)$. Between monitoring flights and

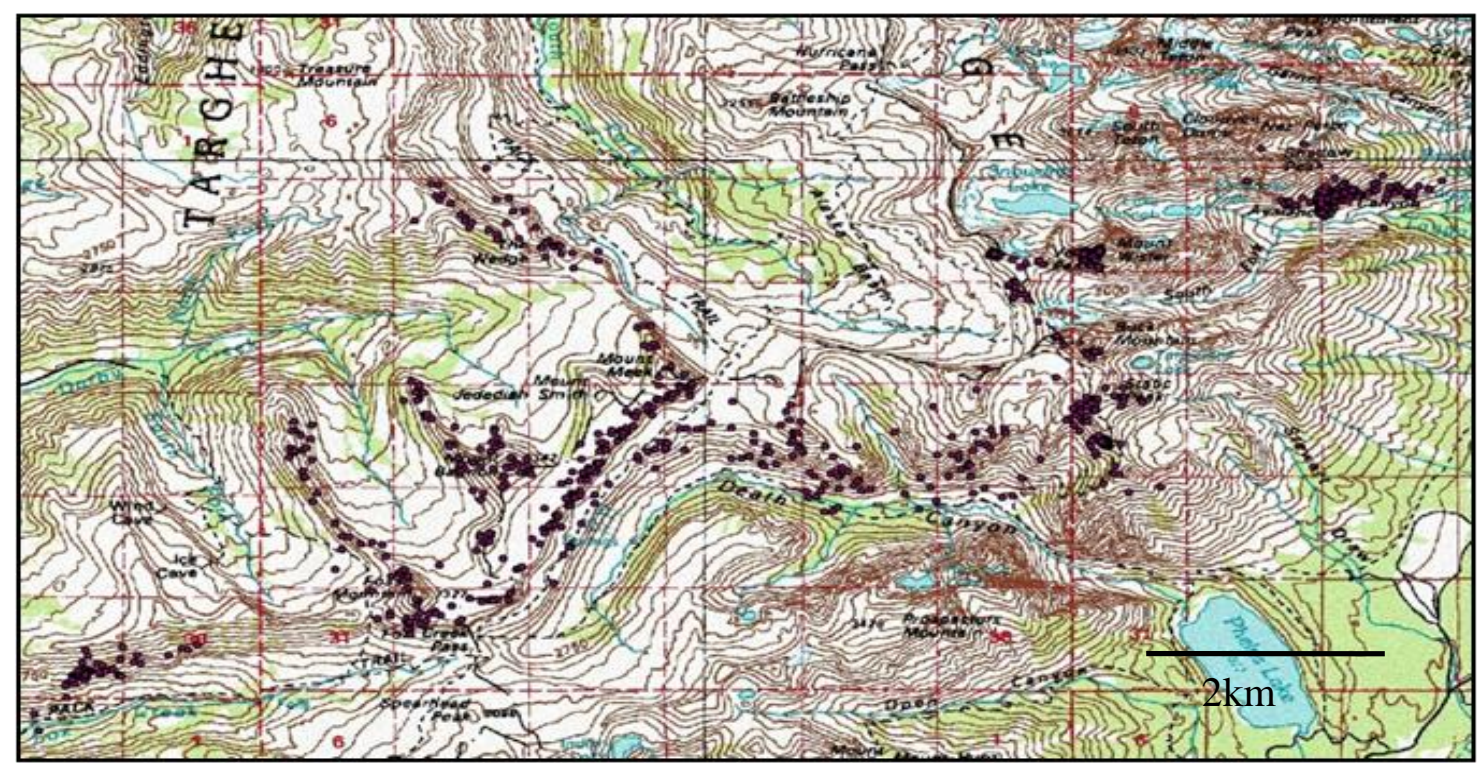

Figure 3. GPS location data downloaded from ewe 543. The GPS-collar was retrieved after the ewe died in an avalanche in December 2009, 10 months after capture. 
ground observations, we documented different movement tendencies between GPS-collared ewes during the summer seasons. Movements ranged from $5 \mathrm{~km}$ throughout the summer, up to a maximum of 15 $\mathrm{km}$. Once we are able to collect the GPS-collars in July 2010 and download locations for each sheep, we will be able to gain a better understanding of the habitat selection strategies driving these movement differences (Figure 4).

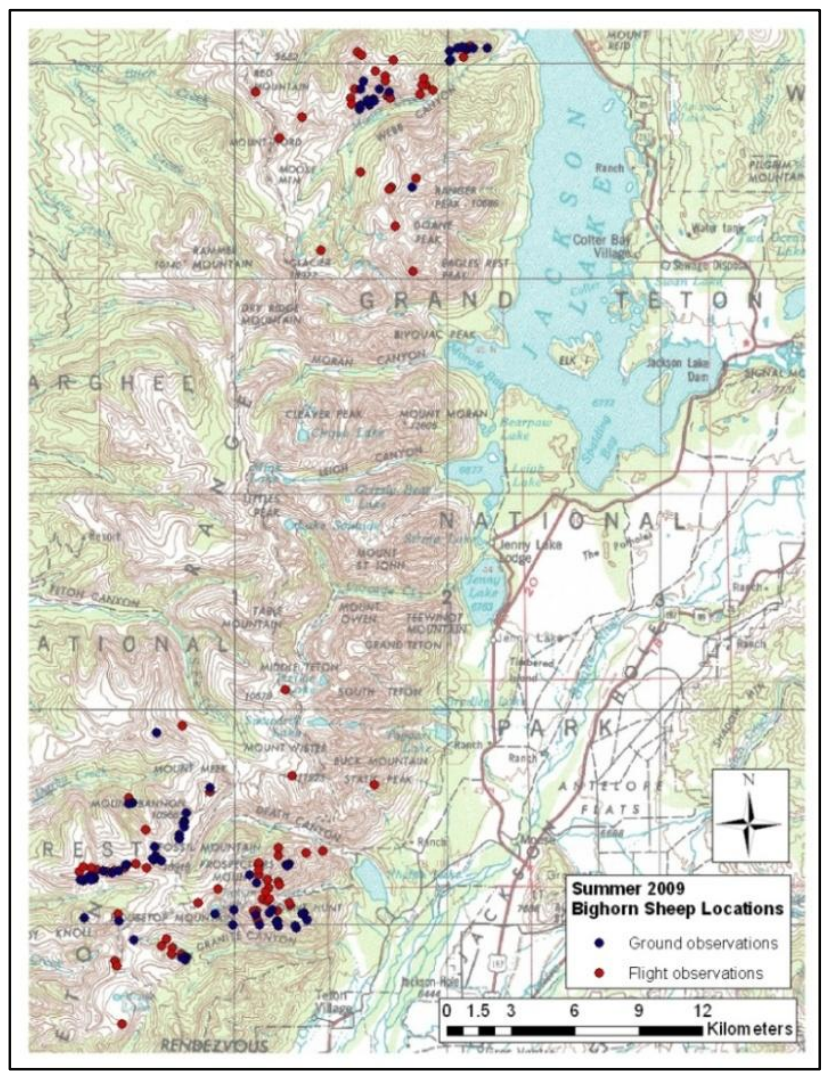

Figure 4. Flight (red) and ground (blue) observations of bighorn sheep groups during summer 2009.

\section{Diet composition}

During summer 2009, we conducted 20 vegetation surveys at locations where bighorn sheep were observed foraging. Over summers 2008 and 2009, we collected 72 fresh bighorn sheep fecal samples, which were analyzed for diet composition. We are currently working on determining forage selection be comparing forage availability in vegetation plots and forage selection in fecal samples. In general, it appears that bighorn sheep in the Teton Range rely most heavily on sedges, grasses, and shrubs early in the summer, and then switch to more forbs later in the summer (while sedges and shrubs decrease in the diet over the summer, grasses are consistent). Major forage plants
(>5\%) include bluegrass (Poa spp.), brome (Bromus spp.), sedges (Carex spp.), milk-vetch (Astragalus spp.), geranium (Geranium spp.), desert parsley (Lomatium spp.), lupine (Lupinus spp.), penstemon (Penstemon spp.), buttercup (Ranunculus spp.), willow (Salix spp.), and snowberry (Symphoricarpos spp.). In total, 36 plant genera were identified in the composite fecal samples. We plan to continue our collection of fecal samples and vegetation surveys in summer 2010.

\section{Time-budgets}

During summer 2008, we completed timebudget observations on 53 individuals within 21 groups. During summer 2009, we completed observations on 60 individuals within 30 groups. We began time-budget observations when groups were foraging. Bighorn sheep spent most of their time feeding $(42 \%)$ or licking mineral deposits (15\%) during summer 2009 (Figure 5).

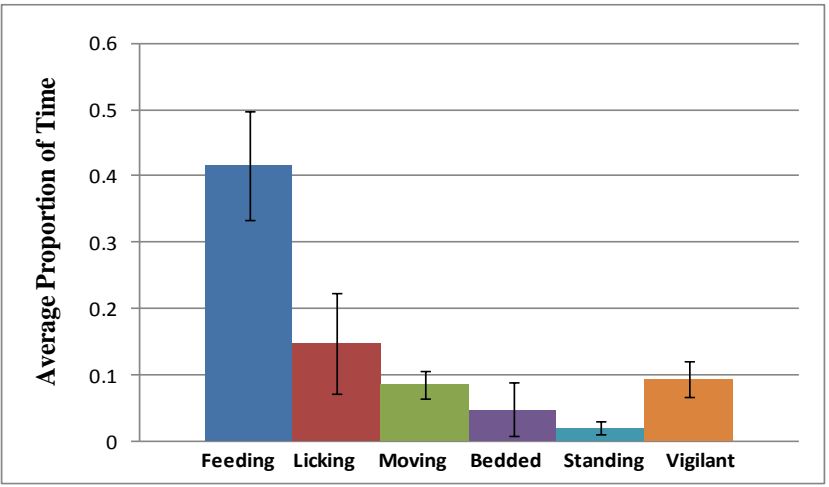

Figure 5. Time-budget observations for summer 2009, depicting average proportion of time spent for different behaviors ( $n=60$ sheep). Most time is spent feeding or licking mineral deposits from rocks.

\section{$\uparrow \quad$ MANAGEMENT IMPLICATIONS}

The Teton Range bighorn sheep population has lost access to its historical winter range and migration patterns, which are threats facing many ungulate populations today. Results from this study will shed light on how this bighorn sheep population has adapted to wintering at high-elevations yearround and how the habitat selection strategies are different from migratory populations. This study will expand our understanding of the consequences of loss of migration on ungulate populations, the strategies that some may develop in order to persist, and the taxa and ecosystems that may more easily support non-migratory populations. 
The results from this project will immediately contribute to decision-making by local wildlife managers at GTNP, BTNF, CTNF, and the WGFD and inform effective future bighorn sheep conservation and management strategies in the Teton Range. Knowledge of the foraging and habitat selection strategies use by this population to cope with living year-round on summer range will inform future management efforts to sustain this small sheep herd. This study will be completed in 2010 and results will be published in peer-reviewed scientific literature and presented at various national and regional scientific conferences.

\section{$\uparrow \quad$ Literature CiTED}

Berger J. 1978. Group size, foraging, and antipredator ploys: an analysis of bighorn sheep decisions. Behavioral Ecology \& Sociobiology 4:91-99.

Bleich VC, Wehausen JD, Holl SA. 1990. Desertdwelling mountain sheep: conservation implications of a naturally fragmented distribution. Conservation Biology, 4:383390.

Bolger DT, Newmark WD, Morrison TA, Doak DF. 2008. The need for integrative approaches to understand and conserve migratory ungulates. Ecology Letters 11:63-77.

Buechner HK. 1960. The bighorn sheep in the United States, its past, present, and future. Wildlife Monographs 4:3-174.

Frid A. 1997. Vigilance by female Dall's sheep: interactions between predation risk factors. Animal Behavior 53:799-808.

Geist V. 1971. Mountain sheep: a study in behavior and evolution. Chicago, IL: University of Chicago Press.

Hebert DM. 1973. Altitudinal migration as a factor in the nutrition of bighorn sheep. [Unpublished doctoral dissertation]. [Vancouver, Canada] University of British Columbia.

Hurley KP. 1996. History of transplanting mountain goats and mountain sheep - Wyoming. Proceedings of the Biennial Symposium of the Northern Wild Sheep and Goat Council, 10:205-209.
Klein DR. 1965. Ecology of deer range in Alaska. Ecological Monographs 35:259-284.

Lung MA, Childress MJ. 2006. The influence of conspecifics and predation risk on the vigilance of elk (Cervus elaphus) in Yellowstone National Park. Behavioral Ecology 18:12-20.

Mwangi EM. 1998. Large herbivore dynamics in the face of the insularization of Lake Nakuru National Park, Kenya. African Journal of Ecology 36:276-279.

Newmark WD. 1996. Insularization of Tanzanian parks and the local extinction of large mammals. Conservation Biology 10:15491556.

Ottichilo WK, deLeeuw J, Prins HHT. 2001. Population trends of resident wildebeest [Connochaetes taurinus hecki (Neumann)] and factors influencing them in the Masai Mara ecosystem, Kenya. Biological Conservation 97:271-282.

Reid ME, Cain SL. 1996. Movements, distribution, mortality, and genetic status of bighorn sheep in the Teton Range: a progress report. USDI, National Park Service, Grand Teton National Park, Moose, Wyoming, USA. Unpublished report. $5 \mathrm{pp}$.

Risenhoover KL, Bailey JA, Wakelyn LA. 1988. Assessing the Rocky Mountain bighorn sheep management problem. Wildlife Society Bulletin 16:346-352.

Serneels S, Lambin ER. 2001. Impact of land-use changes on wildebeest migration in the northern part of the Serengeti -Mara ecosystem. Journal of Biogeography 28:391407.

Shackleton DM, Shank CC., Wikeem BM. 1999. Natural history of Rocky Mountain and California bighorn sheep. In: Valdez R, Krausman P.R., editors., Mountain sheep of North America Tucson (AZ): The University of Arizona Press. P.78-138.

Teton Range Bighorn Sheep Working Group. (1996). Strategic Plan for Managing Bighorn Sheep in the Teton Range. 24pp. 
Valdez R, Krausman PR. 1999. Description, distribution, and abundance of mountain sheep in North America. In:Valdez R. \& Krausman PR, editors. Mountain sheep of North America. Tucson (AZ):The University of Arizona Press. P.3-22.
Whitfield MB. 1983. Bighorn sheep history, distributions, and habitat relationships in the Teton Mountain Range, Wyoming. [Thesis] [Boise (ID)]:Idaho State University. 